research and other departments of the MetropolitanVickers Electrical Co., Ltd. Sir Arthur paid tribute to the pioneer work of Mr. J. G. Pearce in the development of this service, the cost of which now he put at about $£ 10,000$ a year. A recent development is the issue weekly from 1945, in response to a request from the works senior staff, of an Industrial Digest, each number of which contains about fifty brief abstracts on factory processes and workshop practice likely to be of interest to factory executives.

Sir Arthur Fleming's paper was followed by one from Prof. R. S. Hutton on the communication of specialist information to business executives, in which he emphasized that the problem of bridging the gap between the academic world and the so-called practical man is essentially one of interpretation. There are psychological factors, and the scientific worker sometimes pays too little attention to the consideration of the most appropriate form of communication ; but Prof. Hutton stressed the importance of clear and brief exposition. Reforring to T. H. Huxley and W. H. Hudson as examples, he urged that however important clear expression and the planning of reports may be, the prime necessity is to concentrate attention on the actual target to which one's written or spoken word is directed. This aspect of the work of the research associations is of increasing importance, and Prof. Hutton concluded his paper with some hints to the individual information officer and a plea for more imagination, alertness and experience to be brought to bear on the problems of exposition and interpretation. While Prof. Hutton's remarks were generally appreciated, it seemed clear from the brief discussion which followed that the effective communication of scientific and technical information demands not merely much skill on the part of the research worker and information officer but also a considerable improvement in the general standard of education and scientific training of the average business executive himself. An evening session at which Dr. L. J. Comrie, of the Scientific Computing Service, Ltd., presented a paper on "Machines and Tables" closed the proceedings on September 14.

The opening session on September 15, over which Mr. A. E. Cummins presided, was given over to a symposium of papers on some aspects of documenta. tion in Europe to-day. Although short papers by John Ansteinsson on special library facilities in Norway, by Dr. F. Steggerda on the present position of information services in the Netherlands, by Dr. Erik Hernlin on the technical information service in Sweden, by W. Janicki on the Swiss Centre of Documentation, and by J. Wyart on scientific and technical documentation in France were circulated in advance and not read at the Conference, quite inadequate time was allowed for discussion on present conditions in Germany. If the first paper at this session, by Mrs. J. Lancaster-Jones, on "Some Aspects of the Demand for British Scientific and Technical Books for Europe", could be allowed as a contribution to the particular theme under discussion, Miss Esther Simpson's account of the Society of Visiting Scientists seemed irrelevant, and the Conference's organisers failed to gauge the strength of the desire for full information about the position in Germany, especially from British observers. In the absence of Mr. Ronald Fraser, of the Control Commission for Germany and Austria, present conditions in Germany were described by Colonel P. K. Blount, who had just returned from Germany for the purpose, and by Mr. K. Garsides. It would be impos- sible to do justice to either speaker's contribution here by attempting to summarize their account of the position of the university and technical libraries in the British Zone, beyond the statement that roughly some fifty per cent of the holdings of books in both British and American zones have been destroyed. As regards periodicals, little was added to the picture of ehemical publications given by. Dr. Conant in his report to the American Chemical Society, except to indicate some better prospect of the continuation of "Beilstein's Handbuch". Colonel Blount indicated that British policy favours the resumption of old, rather than the initiation of new, periodicals. The general impression left by the papers themselves, by the chairman's own contribution and by the whole of the lively discussion, was that far too little has been done to secure for Great Britain either books or sets of periodicals published in Germany during the War, and that the energy of the Library of Congress Bureau and other American activities have now left the field bare. Dr. Hutton. eited examples of action taken by the Cambridge University Library which enabled that Library to complete its holdings of the German periodicals to which it had subscribed in 1939, and similar action may have been taken by other British libraries. A resolution moved by the chairman was unanimously adopted, urging the Council to give close consideration to the whole position with the view of urging appropriate action on the British authorities. Beyond this, however, the session gave some disconcerting and melancholy evidence of the obstacles that yet exist to the free interchange of knowledge through the medium of print.

At the afternoon session, over which Mr. E. H. Lindgren presided, Mr. Colin Dean described the organisation of the Central Film Library, and during the session there were shown the films "Library of Congress" and "Book Bargain". The final session, when Dr. J. E. Holmstrom presided, was devoted to a discussion on technical dictionaries and glossaries, which was introduced by Miss M. Gossett.

\section{RE-OPENING OF THE GEOLOGICAL MUSEUM, SOUTH KENSINGTON}

THE Geolofical Museum at South Kensington was re-opengt on September 18 after being closed for seven fears. From 1935, when the new building in Exhibrition Road was opened by the King, then Duke of York, until the outbreak of war, there were considerably more than a million visitors to the Museum, which is still the most modern and well. fitted of its kind in the world. Throughout the War the building was occupied by the headquarters staff of the London Civil Defence Region. The galleries were converted into offices; the more valuable exhibits were evacuated to North Wales, and the remainder were stored. Although a heavy bomb fell on the pavement near the main entrance, and another struck the Geological Survey and Museum offices at the west end of the building, no major structural damage was caused by enemy action; but a vast amount of repair and restoration work has been necessary, including some $15,000 \mathrm{sq}$. ft. of window and roof glazing.

The reconstruction of the exhibits has been taken in hand and has now proceeded far enough for the main hall to be re-opened to the public. Among the more 
striking permanent exhibits in this hall are the unique rotating relief globe $6 \mathrm{ft}$. in diameter coloured to show world geology-this most fortunately survived the explosion of a 1,000 lb. bomb about $50 \mathrm{ft}$. away; illuminated dioramas of past and present scenery; large relief-models of south-eastern England; many hundreds of photographic enlargements of geological subjects ; and the Museum's collection of precious and ornamental stones. There are also three special exhibits of topical interest. The largest of these, "British War-time Geology", illustrates some of the contributions to the war effort made by British geologists in both the industrial and the military spheres.

The examples in the Museum of geological work carried out within the British Isles, which are demonstrated by maps, diagrams, photographs and specimens, include intensive survey and search for outcrop coal, for the ores of iron, lead, zinc, tungsten and tin, and for many other essential minerals such as mica, barytes, fluorspar and sand for the manufacture of optical glass ; the survey and development of underground water-supplies for now factories, camps and aerodromes; and advisory work on the construction of underground factories, ammunition stores and other works.

Other parts of the display now available to the public deal with the application of geology to military operations overseas. Examples are shown of maps prepared by geologists during the planning of each major operation to predict the suitability of enemyoccupied territory for the passage of tanks, and for the rapid construction of airstrips, trenches and campsites. Other maps show the occurrence of rock for road and aerodrome construction and repair, and the prospects of obtaining underground water. There are examples of specially vital work on water supply in Egypt and the Western Desert. A related small exhibit of German military geological, maps shows analogous work done by the enemy; of particular interest is an inch to the mile German map of the Brighton-Eastbourne district, revised to June 1940 in preparation for invasion, bearing notes on landing beaches, geology, topography and water-supply. A third special exhibit of current interest illustrates radioactive minerals from the principal producing localities throughout the world.

\section{$8 / 2$}

\section{THE IRAVAS AND CULTURE GHANGE}

$\mathrm{T}$ HE Irava Alu on the Malabar coast, form a suitably sub ect for a study of culture change as they are allarge and vigorous section of the Hindu compunity. Although not actually caste Hindus, ne her do they belong entirely to the depressed classes, standing as they do at their head. Great changes have come over the life, social and economic, of the Irava since the British rule ; and A. Aiyappan, himself a member of the tribe, is well qualified to record the culture changes wrought by the impact of the West on the Hindus (Bull. Madras Gov. Mus., 1 ; 1944).

Starting with an explanation of his method, Dr. A. Aiyappan describes the setting of the problem, both geographical and historic, and the early political history of the district. There follows a most illuminating section dealing with the caste customs of the district and of the two million Irvanas in particular, fining it down to a certain village which he describes in great detail. He dwells at some length on untouchability, which may almost be said to reach its apotheosis in Malabar; the term is perhaps misleading and the expression 'contact taboo' is to be preferred.

The marriage customs and kinship systems of the Irvana form a most interesting chapter, the domestic life and in-law relationships being sympathetically described. In this caste the rather rare form of marriage, fraternal polyandry, used to be, and to some extent still is, practised, as many as five brothers being married to one wife.

Although the main occupation is the cultivation of coconut palms for the traditional occupation of toddy-making; there is also a good deal of agricultural labour, principally in the rice field. Toddy-tapping is a popular occupation as it only occupies a small portion of the day, although the palms need attention every day, and as a supplier of drinks the toddy drawer enjoys plenty of company. As is customary among Dravidian peoples, the Irvana women work in the fields with the men and are not secluded like those in the north of India. Food, houses and clothing are then described, in common with other economics, including the gains and losses due to culture contact. Further chapters on education, magic and religion, and law and order bring to a close this most interesting study.

On the whole, the author is optimistic regarding the future of this large tribe; he feels that culture contact may produce beneficial results, and is not unhopeful of the ultimate acceptance of the oppressed classes by the Hindus.

K. RISHBEth

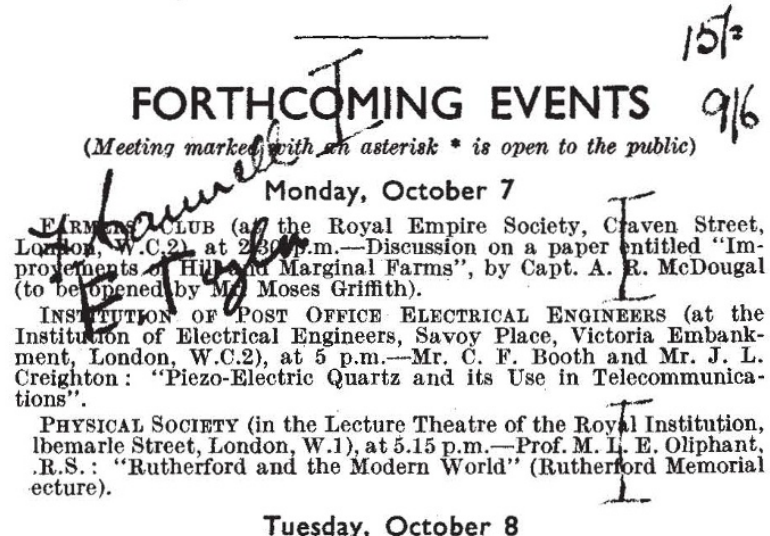
Tuesday, October 8

Chadwiok Public Lecture (at the Royal Society of Tropica Medicine and Hygiene, 26 Portland Place, London, W.1), at 2.30 p.m. -Sir Arthur MacNalty, K.C.B. : "Sir Thomas More as Public Health Reformer".*

Zoological Soctety of LoNdon (at Regent's Fark, London, N.W.8), at 5 p.m.-Scientific Papers.

Institurion of CHEMrcal ENGINEERs (in the Apa tments of the Geological Society, Burington House, Piccadilly, London, W.1), at 5.30 p.m.-Messrs. D. G. Murdoch and M. Cuckney : The Removal of Phenols from Gas Works Ammoniacal Liquor".

Royal Society of MEdicine, SECTION OF EXPERIMERTAL MEdicine AND THERAPEUTICS (at 1 Wimpole Street, London, W.I), at 5.30 p.m. Disease" (Presidential Address).

ILLUMINATING ENGINEERING Societr (at the Schidol of Hygiene and Tropical Medicine, Keppel Street, Gower Street, London, W.C.1), at 6 p.m.-Mr. J. S. Dow : Presidential Address.

INSTITUTE OF FUEL (at Central Hall, Westminster, London, S.W.1), at 6 p.m.- Sir James Chadwick, F.R.S.: Melchett Lecture.

Society of Chemical IndUStry, Plastics Groop tat Burlington House, Piccadilly, London, W.1), at 6.30 p.m.-Mr. N. (J. L. Megson : "Recent Advances in Plastics" (Chairman's Address).

Royal Astronomical Society (at Burlington Houke, Piccadilly, London, W.1), at 8 p.m.--Prof. W. M. Smart: "John Couch Adams and the Discovery of Neptune" (Conversazione). 